\title{
Disagreement as Duty
}

On the Importance of the Self and Friendship in Cavell's Morals Philosophy

Jeroen Gerrits

\section{(2) OpenEdition}

1 Journals

Electronic version

URL: http://journals.openedition.org/ejpap/937

DOI: 10.4000/ejpap.937

ISSN: 2036-4091

\section{Publisher}

Associazione Pragma

\section{Electronic reference}

Jeroen Gerrits, « Disagreement as Duty », European Journal of Pragmatism and American Philosophy [Online], II-1 | 2010, Online since 01 July 2010, connection on 19 April 2019. URL : http:// journals.openedition.org/ejpap/937 ; DOI : 10.4000/ejpap.937

This text was automatically generated on 19 April 2019

\section{(9) $\Theta \Theta \Theta$}

Author retains copyright and grants the European Journal of Pragmatism and American Philosophy right of first publication with the work simultaneously licensed under a Creative Commons AttributionNonCommercial-NoDerivatives 4.0 International License. 


\section{Disagreement as Duty}

On the Importance of the Self and Friendship in Cavell's Morals

Philosophy

Jeroen Gerrits

\section{AUTHOR'S NOTE}

This essay is an edited version of a paper presented at Université de Picardie Jules Verne (Amiens, France) in June 2008 and at the NYU comparative Literature conference entitled "Disagreement" in March 2010.

\section{Introduction}

1 This essay focuses on the significance of disagreement in what Cavell has coined "Emersonian" perfectionism. This moral outlook holds that everyday moral duties and choices, unlike epistemological cases, ultimately rest on our personal assessment and justification of an action. It is therefore possible (and likely) that disagreements point not to moral incompetence, but to a conflict of desires - crucially including a conflict of ones own desires. As a consequence, the demand of making oneself intelligible is a primary and constant moral duty, without which we lose sight of the means of coming to an agreement. Perfectionism further assumes that, since people are not transparent to themselves, conversations with friends form a decisive part of the moral life as well. Thus touching at once on individual needs and desires as well as on the foundations and limits of community, these assumptions challenge both models dominating American moral thinking: (Mill's) utilitarianism and (Kantian) deontology. ${ }^{1}$ I will primarily engage with a critique of the latter model, according to which disagreement merely signifies moral flaws. Moreover, to the extent that self can be distinguished on the basis of inclinations, desires, opinions, and a voice of one's own, Kant, in his demand for the moral realm to be pure and for the voice to be universal, seeks to keep this self out of the moral realm altogether, thus founding what a perfectionist would call as a selfless and friendless 
moral fantasy. To Cavell, the self and its desires and inclinations do not pose a serious threat to moral reasoning - not per se at least. Instead, he aligns himself with a tendency he sees recurring throughout the history of philosophy (and literature, film, etc.); a tendency of thinkers who take conformity of the self to the community speaking for it to be the most threatening attitude, especially in democratic societies. The importance of friendship becomes yet more apparent in this context, as I shall illustrate through Cavell's discussion with Saul Kripke on the moral implication of Wittgenstein's Philosophical Investigations in the second half of this paper. I shall first outline the importance of the self for a perfectionist moral outlook by contrasting it to Kantian deontology.

\section{Vices of Moral Reasoning: Kant and Perfectionism}

According to Cavell's interpretation of Wittgenstein, a philosophy that proceeds by means of grammatical investigations neither aims at having us agree about certain statements or judgments, nor at bringing an individual into communal agreement. The point lies elsewhere, prior to the moment of such (dis)agreement. If we do not say, for example, that we are of the opinion that the world exists, we do not do so because we believe the contrary - that the world does not exist - but because the existence of the world is not a matter that falls within the "grammatical" scope of what we call an opinion. It would likewise be empty to say that we agree on the world's existence - Cavell ironically adds that we may just as well decide that it does. At stake here is an agreement in judgments, without which we would never be able to (dis)agree about anything. That is to say: if our disagreements about opinions are more than mere mutual misunderstandings, we agree about the use of our words that express our opinions - which is far from saying that one could not or should not doubt the existence of the world. The interest of an ordinary language philosopher does not lie in the defense or preservation of ordinary beliefs or common sense, but in learning the particular ground they occupy, whether we agree on them or not. If this ground is to be found in language, this does not mean that one cannot find such grounds to crack.

Disagreements both in and about opinions are crucially included in a moral perfectionist's aspirations. This forms a stark contrast with a Kantian version of moral reasoning, which crucially relies on agreement. In his discussion of Kant's moral philosophy, especially the Groundwork of the Metaphysics of Morals, Cavell highlights the assumption of the existence of two worlds. ${ }^{2}$ In the moral realm, Kant distinguishes one world in which man is determined by laws of causation from another one in which he is free. The latter is the world of Reason - possessor and "bringer of law." But Reason, unlike the Understanding's functioning in the field of sensation, does not impose its force beyond our choice on the other world. Like the forms of the Understanding, the Law of Reason is both universal and necessary, but it is not necessarily obeyed. This in fact forms the cornerstone of Kantian morality: everyone endowed with Reason "ought to" have his or her actions motivated in accordance to the Law of Reason. Kant insists that there is only one Moral Law: the categorical imperative. This imperative - I will stick here to the first of its well-known formulations - comes down to acting "only in accordance to that maxim through which you can at the same time will that it become a universal law" (Kant 1785: Ak. 420-1). The moral task is to realize the liberty characteristic of the realm of Reason into the world otherwise governed by laws of causation. 
4 By positing the existence of two worlds, one of which remains - and always remains - to be realized into the other, Kant inscribes himself, in Cavell's view, into a moral perfectionist tradition that aims to further the self. Yet Cavell objects that we are not always clear about the subjective principles of our actions. And even when we are, we are not necessarily immoral if we do not want them to become universal laws. Yet there is a more pressing point. Assuming that we know our maxim and desire its universalizability, Kant demands that, for our action to be morally right, our obedience to the law must be pure or unconditional. This is to say that actions should not be motivated by inclinations, since inclinations are neither universalizable, nor do they mark our freedom. Cavell has it that, for Kant, the reality of morality is discovered in the overcoming of inclination by duty. Kant's demand for purity further means that we should disregard any results from our actions. So we are not supposed to expect a medal for helping someone in distress. According to a Kantian morality, moral values are determined by intentions of actions rather than by their effects. Regarding this essential Kantian point, Cavell remarks the following:

Is it the case that fulfilling everyday duties (helping someone rather frail onto a trolley, laying in groceries for a friend with the flu, not yielding to favoritism in giving a grade or voting an award, hearing out a friend in grief, not cheating on taxes) gives one a higher moral worth if one fulfills them grimly or affectlessly rather than with occasional feelings of mild satisfaction, mild exasperation, or relief, and with no thought in the world about whether anyone else does such a thing or not? (Cavell 2004: 137)

Bluntly (if less eloquently) put: Cavell is asking, rhetorically, whether it seems fair to say that my (expectation of) feeling good about having done something right devaluates, if not disqualifies, the rightness of my action. With this objection, Cavell parenthetically adds, he may be verging on "moral snobbery" - a characteristic vice, as he calls it, of perfectionist aspirations. But perfectionism is not the only moral outlook with its own inherent vices: from a perfectionist point of view, "affectlessly" performed everyday duties may be called the characteristic vice of the Kantian version of moral reasoning.

This becomes clear in Cavell's discussion of the first of Kant's examples of the workings of the categorical imperative (which is not, I hope, an example of an everyday duty): the case of the man considering suicide. This is Kant's version of the example, starting with his description of the suicidal man's maxim:

"From self-love I make it my principle to shorten my life when its longer duration threatens more troubles than it promises agreeableness." It is seen at once that universalizing this maxim into a law of nature would contradict itself since it uses self-love, which is to further life, to destroy life. Since it could not therefore, be a law of nature, it opposes the supreme principle of all duty, namely the Categorical Imperative. (Kant 1785: Ak. 422)

7 One may wonder whether a suicidal man actually thinks or should think of the action he contemplates in terms of a moral duty at all, to say nothing of the tone in which Kant imagines a suicidal man to express himself. Cavell really wonders, however, how many of Kant's admirers would actually be willing and able to defend the contradiction between maxim and law, and whether they consider this to be a convincing argument in case the suicidal man turns out to be a beloved one. The point being that an affectless conversation of this kind may not be the morally right way to go.

8 Moreover, Kant claims in this example that "it can be seen immediately" that the universalized maxim is self-contradictory. This affirms his view that moral reasoning is 
an intuitive operation, to be exercised by anyone endowed with reason. There cannot - in principle - be any dispute about its outcome. Any two people, in different words, will agree whether a given maxim can or cannot be universally willed and therefore whether an action is right. This is why Kant essentially relies on agreement as the foundation of morality. For Cavell, however, Kant's examples (including the suicidal man) strike him as "fantasies of essentially isolated, friendless people" (Cavell 2004: 133) who do not stand in need of any more company than that of their own reasoning faculty. This contradicts Cavell's observation that readers of Kant often run into trouble when asked to determine "the" maxim of an action. So to be sure: Cavell credits Kant for the insight that actions indeed have maxims. There are reasons for our actions, and to find the ground for these reasons is itself a moral act. In Cavell's phrase, this is to say that acting is a mode of speaking . Yet he brings in against Kant that

[c]onversations in which friends explore whether an act is indeed your duty, meaning any of your business, as well as meaning your inescapable business, and whether if it is, it is to be denied the name of doing your duty if you do it, for example, out of guilt, or remorse, or joy, seem to me to be of the essence of the moral life and to leave open what makes duty real. (Cavell 2004: 133-4)

Far from denying the importance of real duties, then, Cavell aims at Kant's own observation that we can never know absolutely whether or not we are acting, in Kant's words, "in conformity with duty but not from duty" [Ak. 398]. That is: the result of an action may be good while the motivation of that action is not right. In yet other words, while Kant makes it our duty to obey the moral law unconditionally, he affirms that we can never exclude the possibility that some inclination contaminates the purity of our obligation; that we are not, after all, secretly hoping to receive a medal for helping our distressed fellows or that we are not in love with the suicidal man. I have argued above that, for Cavell, such contaminations do not devaluate the moral status of our actions. The point now is this: "That our purity of motivation in obeying the moral law is impenetrable to us is no more mysterious or revelatory about us than that our motives and desires generally are not transparent to us, and that we can, in caring about ourselves, make them less dark" (Cavell 2004: 143).

\section{Moral Implications of Wittgenstein's “Scene of Instruction"}

10 With this conclusion, let us return to Wittgenstein. Kant just called into question whether we can know our conformity to the moral law to be pure. In what is known as the "scene of instruction" in the Investigations, ${ }^{3}$ Wittgenstein asks how we can know, and justify, that we are following a rule or law at all. To be sure, Wittgenstein is not specifically talking about the moral laws or the categorical imperative, but Cavell, as we shall see, seeks to extend his argument to include it. He does so specifically in response to Saul Kripke's interpretation of the same scene of Wittgenstein's. Kripke's interpretation is of interest to Cavell since Kripke, like Cavell, does not interpret the Investigations as attempting to refute skepticism, as so many others have done. Unlike Cavell, however, Kripke takes rules to be fundamental to Wittgenstein's response to the threat of skepticism. He further assumes that Wittgenstein's response has, in Cavell's words, "to do with a particular way of bringing the individual into communal agreement" (Cavell 1990: 66). ${ }^{4}$ 
11 According to the opening paragraph of the Investigations, explanations - and Wittgenstein means all explanations - "come to an end somewhere." In the scene of instruction this translates into the following: "If I have exhausted the justifications I have reached bedrock, and my spade is turned. Then I am inclined to say: 'This is simply what I do"' (Wittgenstein 1953: §217). Wittgenstein's remark specifically answers a question concerning the ability to follow rules. The answer applies, for example, to the question how a pupil should know that he or she is indeed making a mathematical addition when s/he is asked to do so. Yet Cavell's quarrel with Kripke ultimately centers on question of authority in the moral life, and for that reason I want to take a brief look at their respective interpretations, beginning with Kripke's comment on Wittgenstein's exhaustion of justifications. "The entire point of the skeptical argument," Kripke writes, "is ultimately that we reach a level where we act without any reason in terms of which we can justify our action. We act unhesitatingly but blindly" (Kripke 1982: 87). In Kripke's account, our inclination to simply do what we do in the absence of justifying reasons can either be accepted or rejected by someone else, particularly by some representative of the community (say a teacher who judges whether a pupil is, indeed, adding and not multiplying). So my action will be acceptable when my inclination matches with that of someone else.

12 According to Cavell, this interpretation of Wittgenstein is based on a misreading of the phrase "Then I am inclined to say: 'This is simply what I do." He takes Kripke to read this sentence as: "Then I am licensed to say: "This is simply what I am inclined to do." The second of these two sentences, Cavell argues, obscures the fact that when we are inclined to say anything, we do not necessarily go on to actually saying it, meaning that there are considerations against saying that "this is simply what I do." When there are, for all my inclinations, still hesitations, I am exactly not acting "unhesitatingly but blindly," as Kripke had it - especially not in cases in which the justifications for our actions are exhausted.

Kripke's idea, in short, comes down to a public licensing through matching inclinations. According to Cavell, this means that my inclination is but a conformation, which is to say that I do not have an inclination I could properly call my own - something John Stuart Mill, among many others, was warning against. Over and against Kant's idea of morality as the overcoming of inclination by duty, Mill holds (in Cavell's phrase) that "morality is discovered in the overcoming of conformity by inclination or desire." Mill further claims (in a phrase that resonates remarkably well, say, with Heidegger's analysis of "das Mann") that it no longer occurs to anyone "to have any inclination except for what is customary." From this vantage point, Kripke's claim that we act "unhesitatingly" points to a certain self-confidence, but the blindness that goes with it now implies, in Cavell's reading, that we may, for all our confidence, regard ourselves absolved from taking responsibility for our actions and inclinations alike. This becomes all the more pressing when our inclinations do not happen to match, in which case we run the risk of being separated out, of being treated as a morally incompetent person, if not as a lunatic standing in need of being excluded from society. In this light, Kripke's argument now sounds as if he seeks to place those with matching inclinations above reproach.

Reproaching Kripke for this view (and for attributing it to Wittgenstein), Cavell is far from denying that justifications for our actions can and in fact often do come to an end. What he denies, rather, is that all that Wittgenstein's response to skepticism comes down to is to be able to say: "I agree with you, this is my inclination too." "Suppose," Cavell 
rhetorically asks, "that driving you to work I say: 'I'm inclined to run this red light'; if you reply: 'My inclination agrees with yours,' have you licensed me to run the light?" Cavell not only denies this to be the case, he also doubts, as argued above, that a mismatch of inclinations should be indicative of moral incompetence. He rather claims that the moral life exactly starts at the moment of what he calls "intellectual exhaustion" (Cavell 1990: 81), at the point of reasons "coming to an end," or the point at which "there is something, but inevitably so little to say in explanation or justification of my ground" (Cavell 1990: 97). Cavell writes: "If I take your actions as slight or as treachery and refuse to endure them any longer, this judgment is itself my response and my responsibility" (Cavell 1990: 113-4). And for all Kripke's emphasis on the importance of rules in Wittgenstein, Cavell further argues that there is no rule which "tells me when I may end the conversation unilaterally; it is my judgment, not a rule, that lets me conclude that I did what I could" (Cavell 2004: 179). In a word: Judgments, not rules, form the "bedrock" or "finality" or "ground" of morality.

This in fact characterizes moral cases and distinguishes them from epistemological ones. This is first of all the case because the assessment of a moral case, including the description of an action - including its justification and intention - is itself already a moral act. But also, more crucially perhaps, Cavell argues in The Claim of Reason that in moral cases it is ultimately up to me to determine the grounds for doubt. This is not so in epistemological cases, for example the one of the bird with a red head I claim to have seen in the garden and in which I tell you I saw a goldfinch. If you object that there are other birds with red heads (and you name a few), I will either have to specify further why I think this specific kind of bird, was indeed a goldfinch or I must start doubting my claim. A sentence like "I don't care that goldcrests (say) also have red heads," would, on the contrary, provide evidence of my incompetence, not so much in the realm of ornithology as in the realm of language - that is: in the realm of the human.

Contrast this epistemological case with the moral case of a friend challenging my support for a prisoner by claiming that he is an enemy of the state. In this case I may very well counter your objection along the lines of: "I don't care that he is an enemy of the state." This is not to say that there is no limit to moral competence. It would be morally incompetent, for example, to deny the relevance of your doubts or objections. When I say that I do not care that he - say, my brother - is an enemy of the state, I do not deny that it matters at all whether he is such an enemy or not; I am saying, rather, that my brother's being an enemy of the state does not count as a reason for me to doubt my loyalty to him (though it might be for someone else). This can be a perfectly sound moral judgment, whereas I cannot competently say that it does not count as a reason for me that gold crests also have red heads. ${ }^{6}$

17 As Cavell notes, however, the ground for my moral judgment remains open to revision and opposition. No representative of society can license me to say what I say and do what I do, any more than any moral law or rule can justify me beyond reproach. This is not to say that Cavell is licensing me to turn my back on society or to disregard my everyday duties. It is to say that the only one who can justify me is me - the self. But I crucially cannot justify myself by myself:

What justifies what I do and say is, I feel like saying, me - the fact that I can respond to an indefinite range of responses of the other, and that the other, for my spade not to be stopped, must respond to me, in which case my justification may be furthered by keeping still. The requirement of purity imposed by philosophy now 
looks like a wish to leave me out, I mean each of us, the self, with its arbitrary needs and unruly desires. (Cavell 1990: 77) in isolation, nor, as in Kripke's case, by having my own inclinations conform with those of the community (or its representatives). For Cavell, I justify myself in my responsiveness to the other - in conversation with a friend especially. Cavell argues that it may always be the case that our inclinations do not match; that we shall not arrive at an agreement; that consequently I decide to end our conversation. Yet agreement is not the primary aim of conversations on moral issues. The question is rather: when, at what point, do I end the conversation? Did I do everything I could to prevent it? Can I (sometimes indeed) feel satisfied by pointing out a contradiction in your reply and leave it at that? How do my reasons enter the conversation, in what tone do I express them, with what degree of authority or of accusation? any conversation would be futile unless agreement is to be hoped for. Yet it is more important in moral reasoning that a judgment is mine than that it is sound. And it is perhaps yet more crucial that my friend, far from aiming to win an argument, offers alternatives to my view. A friend, for Cavell, is an Aristotelian, a Nietzschean, and an Emersonian: it is my most worthy enemy - confrontational and challenging - whose standard I am constrained to accept. Yet unlike Kant's constraint of duty, the friend's significance lies in his constraint through attraction. "Moral reasoning," Cavell writes in that regard, "is not to take me from irrational to rational choice [...] nor from a will corrupted by sensuous concerns to one measured and chastened by the demands of the moral law [...] but to take me from confusion to (relative) clarity in seeking a world I can want" (Cavell 2004: 32, emphasis added). Far from opposing them to enemies or from distinguishing them from family members (why? even texts can be friends), friends represent the unattained yet attainable self. Moreover, and finally, there is a political dimension tying friendship (and thus the self) to the issue of democracy.

Although agreement or consent is not, from a perfectionist point of view, the aim of moral or political reasoning, it is not the case either that, for that reason, I do not or ought not to give my consent to my community or society. Yet in doing so, Cavell writes, "I recognize the society and its government, so constituted, as mine; which means that I am answerable not merely to it, but for it" (Cavell 1982: 23). ${ }^{7}$ Rather, the political is one among many areas that offers as many possibilities as constraints for finding one's own voice, as well as for exploring what that voice represents. Conformity marks the failure of such attempts, but also manages to keep this failure from view; remember Mill saying not only that we no longer have any inclination except for what is customary, but also that this does not occur to anyone. So the challenge of making oneself less dark is a matter of political responsibility. This is to say that, in a democracy at least, it is not enough to cooperate - cooperation being the cornerstone of Rawls' Theory of Justice..$^{8}$ Unlike Rawls, Cavell does not attempt to provide criteria for a society that could pass as being good enough. And while he agrees with Rawls that our consent is asked for, he does not agree that we should provide it on a conditional basis (as Rawls does), but on a provisional one: he asks us to give our consent from above. In other words: unlike a Rawlsian, the perfectionist does not consent to an ideal society. He or she rather takes the present society to heart, only to demand its change as a whole: by attaining to a further self, a 
perfectionist takes on responsibility for the relative proximity or distance, not from a principle, but from a less unacceptable world.

\section{BIBLIOGRAPHY}

CAVELl S., (1968), Must We Mean What We Say?: A Book of Essays, New York, Cambridge University

Press.

CAVELL S., (1982), The Claim of Reason: Wittgenstein, Skepticism, Morality, and Tragedy, Oxford/New York, Oxford University Press.

CAVELL S., (1989), This New Yet Unapproachable America: Lectures After Emerson, After Wittgenstein, Albuquerque, Living Batch Press.

CAVELL S., (1990), Conditions Handsome and Unhandsome: The Constitution of Emersonian Perfectionism, Chicago, University of Chicago Press.

CAVELL S., (2003), Emerson's Transcendental Etudes, Stanford, Stanford University Press.

CAVELL S., (2004), Cities of Words: Pedagogical Letters on a Register of the Moral Life, Cambridge, MA, The Belknap Press of Harvard UP.

GERRITS J., (2010), “Exiger le changement du monde tout entier: de la portée et de la pertinence politique du perfectionnisme moral," forthcoming in Laugier S., (ed.), La voix et la vertu: variétés du perfectionnisme moral, Paris, Presses Universitaires de France.

KANT I, (1785/1998), Groundwork of the Metaphysics of Morals, trans. M. Gregor, Cambridge,

Cambridge University Press.

KRIPKE S., (1982), Wittgenstein on Rules and Private Language: An Elementary Exposition, Cambridge, Harvard UP.

MILL J. S., (1859/2009), On Liberty: And Other Essays, New York, Kaplan Publishing.

RAWLS J., (1971), A Theory of Justice, Cambridge, MA., Harvard UP, Belknap Press.

WITTGENSTEIN L., (1953/2009), Philosophical Investigations, Malden, MA, Wiley-Blackwell.

\section{NOTES}

1. Cavell is careful not to conceive of moral perfectionism as an alternative to either utilitarianism or deontology. Instead of speaking of a theory, he consistently refers to perfectionism as an "outlook," which, rather than setting limits to morally sound judgments, seeks to explore new venues and perspectives for an attainable future self. Both Kant and Mill have important "contributions" to make to such an outlook, while perfectionism offers valuable critiques in return.

2. Cavell 2004. In this paper, all citations of Kant's work are from the Groundwork as quoted by Cavell.

3. Wittgenstein (1953: § 217). 
4. For Kripke's interpretation of the scene of instruction, see especially Kripke (1982: 79-89).

5. See Mill (2009: 74); quoted in Cavell (2004: 96-7).

6. On this point, see also Gerrits 2010.

7. On the importance of Cavell's view that I am not constituted outside of the political or social realm (as many liberalists hold), see Hammer 2002, esp. 128-37.

8. On this final point, see Gerrits 2010.

\section{AUTHOR}

\section{JEROEN GERRITS}

Binghamton University/State University of New York jgerrits[at]binghamton.edu 